\title{
Liberal Education and Politics
}

\section{David Bolotin}

Liberal education is education appropriate to a free human being, or education toward the proper cultivation of freedom. It has always been contrasted with education that aims merely at teaching specialized skills that prepare students to earn a living. And it has always had one or both of two primary emphases. The first of these is education for citizenship, citizenship in a free and self-governing society. This is rightly thought to be necessary on the grounds that responsible citizenship requires a broad understanding of human life, and even of the place of human life in the larger whole.

And yet the freedom of a responsible citizen is not freedom simply, since every political society rests on certain unquestioned assumptions that one doesn't choose freely, but that one is born and bred into, as it were. And those educators, such as Plato, who were sensitive to this fact saw that liberal education must have a second aim, the aim of a truer and more complete freedom, rooted in freedom of the mind. Such freedom requires a questioning of all inherited assumptions, including the most fundamental assumptions of one's political society-not necessarily a rejection of them, but at least an openness to the possibility that they are wholly or partly false. Now it is this second, and in my view, higher, understanding of liberal education that I wish to focus on here, and in particular on the obstacles that stand in its way.

The former dean of the College, Jacob Klein, wrote in his essay "The Idea of Liberal Education" that the most serious obstacle to liberal education is precisely its relation to the political community. ${ }^{1}$ I agree with this statement, and let me try to say why. I begin by reading a passage from Book Six of Plato's Republic. Socrates says there to Adeimantus,

1 Jacob Klein, Lecture and Essays (St. John's College Press, 2013), 168.

David Bolotin is tutor emeritus at St. John's College in Santa Fe. The following piece is the text of informal remarks he delivered on December 9, 2020 as part of a panel discussion sponsored by the College's Student Committee on Instruction on the topic of "Politics, Liberal Education, and the [St. John's] Program." St. John's College offers a world-renowned Great Books education and has campuses in Annapolis, MD and Santa Fe, NM. 
Well, then, I suppose that if the nature we set down for the philosopher chances on a suitable course of learning, it will necessarily grow and come to every kind of virtue; but if it isn't sown, planted, and nourished in what's suitable, it will come to all the opposite, unless one of the gods chances to assist it. Or do you too believe, as do the many, that certain young men are corrupted by sophists, and there are certain sophists who in a private capacity corrupt to an extent worth mentioning? Isn't it rather the very men who say this who are the biggest sophists, who educate most perfectly and who turn out young and old, men and women, just the way they want them to be?

"But when do they do that?" he said.

When, I said, many gathered together sit down in assemblies, courts, theaters, army camps, or any other common meeting of a multitude, and with a great deal of uproar, blame some of the things said or done, and praise others, both in excess, shouting and clapping; and, besides, the rocks and the very place surrounding them echo and redouble the uproar of blame and praise. Now in such circumstances, as the saying goes, what do you suppose is the state of the young man's heart? Or what kind of private education will hold out for him and not be swept away by such blame and praise and go, borne by the flood, wherever it tends so that he'll say the same things are noble and base as they do, practice what they practice, and be such as they are?

“The necessity is great, Socrates," he said.

And yet, I said, we still haven't mentioned the greatest necessity. "What?" he said.

What these educators and sophists inflict in deed when they fail to persuade in speech. Or don't you know that they punish the man who's not persuaded with dishonor, fines, and death?

"Yes," he said, "they punish very severely."

So what other sophist or what sort of private speeches do you suppose will go counter to these and prevail?

"I don’t suppose any will," he said. ${ }^{2}$

2 Republic 492a1-e1, Bloom translation. 
Now this passage clearly means that the political community is the greatest obstacle to the education of a philosopher. But is the claim true? Is it true today? I think it is. And to show that it is, let me first remind you of the ruling opinions of our own political society. These are, I think, a belief in equality and a belief in freedom. We are taught that we are all equal, and we are also taught that we have the right to a very great degree of freedom, so long as this freedom doesn't stand in the way of the equality of all. A few generations ago, I might have said that our fundamental opinions are a belief in freedom first and equality second, with equality understood as equality of opportunity. But that equality has come, more and more, to be measured by equality of results, in the sense of parity for all groups, and so I think that the belief in equality is today even more fundamental than the belief in freedom.

Now the Great Books that we read at St. John's might well appear to invite us to reflect on these convictions, to question them and to consider alternatives. For to take only the most obvious among many examples, Aristotle says in Book I of the Politics that men are superior to women on the grounds that the rational faculty, which belongs of course to both sexes, has greater power or authority within the souls of men.

And yet even though I taught freshman seminar many times in my years as a tutor, this simple assertion was never discussed, nor do I know of any other tutor's seminar in which it was discussed, except for an occasional brief condemnation of Aristotle as a sexist. And similarly with other topics, especially those that relate to sexuality, with regard to which many of the authors we read are critical of our contemporary beliefs and practices. There is no discussion of these matters in class. In other words, we read the books, but we never even entertain the possibility that what they say is true. Which is to say that we don't really read the books.

But why don't we? Why are the clear opportunities that our Program offers for reflection on our political and moral convictions not taken up? Well, the most visible and most immediate reason, I would say, is because of what is known as political correctness or the cancel culture. For just as Plato wrote in the passage I read from the Republic, it isn't safe to challenge contemporary orthodoxy. To be sure, there is no threat of imprisonment or death. But the threats to one's reputation and even livelihood are very great indeed.

Some of you may remember that the former president of Harvard, Larry Summers, was forced to resign, in large part because he had said that the 
underrepresentation of women in the sciences might be due in part to natural differences between the sexes. Or more recently, an engineer from Google was fired for sending social media messages to the same effect regarding the relative lack of women engineers at the company. And you may also have heard of the executive from Boeing who was fired recently for having written-back in 1987-that women were not cut out to be fighter pilots. Or, to take another related issue, you may have heard of the three men who were fired from Cisco for having said, in their obligatory training session on diversity and inclusion, that they disapproved of the Black Lives Matter movement. Or, to mention still another issue, the CEO of the Mozilla corporation, which operates the Firefox browser, was forced to resign after only a week on the job when it was discovered that he had donated a thousand dollars to a campaign in California against same-sex marriage. And finally, to take an example closer to home, two years ago an Annapolis tutor was accused of gender discrimination under Title IX because he had been unwilling to refer to a student, present in the room with him in a don rag, with the student's preferred pronoun "they." ${ }^{3}$ He could have been fired for this, despite his having tenure, though after months of investigation and hearings, he escaped punishment on the grounds of insufficient evidence. But he was also told that if he appealed the decision's having been made on these grounds and tried to argue that the College didn't have a pronoun requirement, things could get worse for him.

Now I have listed only a handful of instances, but I could have added others, and you all must know that it takes only a few visible punishments to establish an atmosphere of fear and intimidation. And I ask, how did it come to this? How did a country with the principle of freedom of speech enshrined in the First Amendment to the Constitution come to be so intolerant of dissent? I don't have an adequate answer to this question, and I don't deny the role of simple zeal to eradicate what is thought to be evil. But it also seems important to me that “we”-by which I mean the so-called educated class in our society-are philosophic relativists. We are not relativists in the full sense that we think all opinions are equally valid, which of course we don't, but relativists in the sense, at least, that we don't think rational inquiry can resolve fundamental questions of value. Thus, if people disagree with us about basic moral or political questions,

3 The don rag evaluation process is a tradition that dates back generations at St. John's college. Basically, students meet with around five tutors near the end of each semester of their freshman through junior years to receive an oral report on their progress. See Tim Pratt, "Don Rags: A Lasting Impact," St. John's College, November 16, 2016, https://www.sjc.edu/news/don-rags-lasting-impact. 
we no longer think, as the authors of the First Amendment did, or as John Stuart Mill did, that free and open discussion can bring society as a whole closer to the truth. Instead, when someone disagrees with convictions to which we are passionately attached, we tend to be simply uncomfortable and irritated.

This is a large part of the reason, I think, that we try to silence opposition; for if no one speaks up against our convictions, we can more easily avoid the worry that they might be wholly or partly wrong. Still, I don't think that this is the main reason why the Program has been as unsuccessful as it has been in promoting freedom of thought. For this lack of success goes back many decades, long before the pressure for political conformity became as great as it is now. And so let me offer an additional hypothesis as to why our political convictions have resisted questioning and examination.

Modern society demands, relatively speaking, very little of us, and it legitimizes many pleasures to which we have become quite attached. For many generations, the pursuit of pleasure, in whatever form we choose, has become more and more respectable, and to question our moral and political convictions can therefore seem like looking a gift horse in the mouth, and so we don't do it.

On the other hand, the very permissiveness and absence of high demands that are so characteristic of our modern democracies also lead, in some of the young, to discontent and a feeling of emptiness in their lives. This discontent helps to fuel, I think, the egalitarian zeal of our new moralists, since that zeal seems to offer an escape from the unsatisfying pursuit of pleasure. But I suspect that this discontent has also been a factor leading some of you to St. John's, where, relativistic dogma notwithstanding, you hoped to learn what virtue and the good life truly are. And my advice to you is to keep heeding your discontent, along with the doubts that it awakens, to discuss these doubts, to the extent possible, both in and out of class, and to respect the power of your minds to help guide you toward a better life, a power that may be much greater than you imagine. 